\title{
TRADD Gene
}

National Cancer Institute

\section{Source}

National Cancer Institute. TRADD Gene. NCI Thesaurus. Code C28652.

This gene plays a role in signal transduction and regulation of apoptosis. 